\title{
Narcisismo e seus ecos
}

\author{
Ana Paula Lacorte Gianesi
}

\begin{abstract}
Resumo
Este artigo propõe extrair do mito de Narciso seus componentes estruturais e seguir com possíveis críticas ao degredo do laço social contemporâneo. A presença das ordens paterna e pulsional no mito e no destino trágico do herói grego é crucial para a sustentação dos argumentos aqui apresentados. Narciso era filho de Cefiso (um rio). As águas (como espelho-Outro) estavam postas desde o início da narrativa. As dimensões do olhar e da voz (como objetos pulsionais) apresentam-se de modo reificado: o olhar que aprisiona e a voz que surge petrificada e em profunda alienação (ecolalia). A orientação ética de uma análise, que visa ao esvaziamento do sentido e à sustentação do furo próprio ao Real, seria um contraponto ao inflar narcísico e à voracidade dos espetáculos de sentido. O presente trabalho se encerra com uma proposta de distinção entre o que seria um fim de análise por o que se pode designar como identificação narcísica (quando os elos do sintoma e do Imaginário atam-se por homotopia) e quando ocorre, por um ponto vazio, enigmático, a identificação ao sinthoma (o que coloca em continuidade Real e sinthoma).
\end{abstract}

\author{
Palavras-chave: \\ Narcisismo; Identificação; Topologia; Homotopia.
}

\section{Narcissism and its echoes}

\begin{abstract}
Drawing from the myth of Narcissus its structural components, this article aims to critically debate some aspects on the degeneration of the contemporary social bond. The presence of paternal and drivers dimensions in the myth and the tragic destiny of the Greek hero is seen as crucial to support the arguments placed here. Narcissus was the son of Cephus (a river). The waters (as mirror-Other) were laid from the beginning of the narrative. The elements of the gaze and the voice (as libidinal objects) appear in a reified way: the gaze that imprisons and the voice that emerges in petrified and deep alienation (echolalia). The ethical orientation of an analysis, which aims to empty the meaning and sustain the gap of the Real, would
\end{abstract}


be a counterpoint to the narcissistic influx and to the voracity of the spectacles of meaning. The present work ends with a proposal for the distinction between what it would be an end of analysis through what can be designated as narcisic identification (when the links of the symptom and the Imaginary are tied by homotopia) and when it happens by a void, enigmatic, there is an identification of the sinthome (which puts into continuity the Real and the sinthome).

\section{Keywords:}

Narcissism; Identification; Topology; Homotopia.

\section{Narcisismo y sus ecos}

\section{Resumen}

Este artículo propone extraer del mito de Narciso sus componentes estructurales y seguir con posibles críticas al degredo del lazo social contemporáneo. La presencia de las órdenes paterna y pulsional en el mito y en el destino trágico del héroe griego es crucial para la sustentación de los argumentos aquí planteados. Narciso era hijo de Cefiso (un río). Las aguas (como espejo-Otro) estaban puestas desde el principio de la narrativa. Las dimensiones de la mirada y de la voz (como objetos pulsionales) se presentan de modo reificado: la mirada que aprisiona y la voz que surge petrificada y en profunda alienación (ecolalia). La orientación ética de un análisis, que busca el vaciamiento del sentido y la sustentación del agujero propio al Real, sería un contrapunto al inflar narcísico y a la voracidad de los espectáculos de sentido. El presente trabajo se encierra con una propuesta de distinción entre lo que sería un fin de análisis por lo que se puede designar como "identificación narcísica" (cuando los enlaces del síntoma y del Imaginario se atam por homotopía) y cuando ocurre, por un punto vacío, enigmático, la identificación al sinthoma (lo que pone en continuidad Real y sinthoma).

\section{Palabras clave:}

Narcisismo; Identificación; Topología; Homotopía.

\section{Narcissisme et ses échos}

\section{Résumé}

Cet article se propose d'extraire les éléments structuraux du mythe de Narcisse, tout en faisant une critique de l'exil forcé du lien social contemporain. La présence des ordres paternels et pultionnels dans le mythe et dans le destin tragique du 
héros grec est capitale pour soutenir les arguments ici proposés. Narcisse était le fils de Céphus (une rivière) ; soit, les eaux (en tant que miroir-Autre) y étaient présentes dès le début. Les dimensions du regard et de la voix (en tant qu'objets pulsionnels) sont alors présentés de manière réifiée : le regard emprisonne, et la voix surgit pétrifiée et en profonde aliénation (écholalie). L'orientation éthique d'une analyse, qui vise à vider le sens et à soutenir le trou propre au Réel, serait un contrepoint au gonflement narcissique et à la voracité des spectacles de sens. On conclut par une proposition de distinction entre ce qui serait une fin d'analyse par ce qui peut être nomé comme identification narcissique (lorsque les liens du symptôme et de l'Imaginaire sont noués par homotopie) et quand il se produit, par un point vide, énigmatique, l'identification au sinthome (qui met Réel et sinthome en continuité).

\section{Mots-clés :}

Narcissisme; Identification ; Topologie ; Homotopie.

Que é um eco senão a

transformação de uma voz em

pedra, no eternamente idêntico a

si mesmo, como fazem as letras

do alfabeto.

(Leminski)

\section{Cefiso-pai}

Narciso era filho do rio Cefiso - do grego Képhisos -, "o que banha, o que inunda", e da Ninfa Liríope (nome que pode significar "voz macia como um lírio") (Brandão, 2013, p. 182).

Inundado pela recorrente simbólica das águas e por uma importante referência à voz, o mito de Narciso, em seus desfechos, revela o herói trágico enclausurado em uma fonte (seu espelho) e a voz convertida em pedra, puro eco. Imagem (olhar) e voz aprisionadas, cárcere sustentado, justamente, por um apoio paterno. Afinal, parece não ser irrelevante que Narciso fosse filho de um rio. E resta ainda curioso que, possivelmente, o nome de sua mãe remeta a algo da voz.

Um dos símbolos do rio, do "escoamento" das águas, é a fertilidade. Acrescentemos, de passagem, que determinados "seres" primordiais, como rios e montes, entre outros, talvez por não se terem antropomorfizado, eram detentores de uma grande energia sexual (...). O fato é que são inúmeros os filhos de oceanos, rios e montes... Ora, se as ninfas (...) são divindades 
também ligadas à água, vamos ter em Narciso e narciso [flor] dois enamorados das águas. (Brandão, 2013, p. 182, grifo nosso)

Assim como tantos outros personagens da mitologia grega, Narciso não escapou de certo elemento de destino. Sua mãe, Liríope, havia consultado Tirésias (cego vidente/profeta) sobre a longevidade de seu filho. $\mathrm{O}$ adivinho lhe respondeu que sim, que aquele muito viveria, "se ele não se conhecer" (Ovídio, 8 d.C./2017, p. 187). Pois bem, Narciso entorpeceu-se, deixou-se enfeitiçar por sua própria imagem refletida na límpida e pura fonte de Téspias. Maldição de Nêmesis, que o havia condenado a amar um amor impossível. A pedido de algumas ninfas, indignadas com a frieza de Narciso diante da tragédia de Eco, Nêmesis o amaldiçoara.

Eco, por sua vez, teria sido condenada por Hera a não mais conseguir falar. Ela poderia apenas repetir os últimos sons das palavras que ouvisse.

Tão friamente repelida, mas ardendo em paixão por Narciso, Eco se isolou e se fechou numa imensa solidão. Por fim, deixou de se alimentar e definhou, transformando-se num rochedo, capaz apenas de repetir os derradeiros sons do que se diz. As demais ninfas, irritadas com a insensibilidade e a frieza do filho de Liríope, pediram vingança a Nêmesis (...). (Brandão, 2013, p. 186)

O aprisionamento de Narciso (em sua imagem) parece não vir sem determinado tratamento da voz. A petrificação da voz, que a imobilização de Eco traduz, reduz qualquer dizer a repetições derradeiras, ecolalias em negação de qualquer laço possível. Pode-se pensar, destarte, que Narciso precisa de Eco na mesma medida (dialética) em que o senhor precisa do escravo (em referência à dialética proposta por Hegel). Talvez, Narcisos precisem de idólatras-pedras a repetir seus sons, seus ditos, seus maneirismos, suas últimas palavras.

No mito de Narciso, narrado pelo mitógrafo grego Cônon (cerca de 30 a.C.), o jovem é descrito como "extremamente belo, mas orgulhoso para com Eros e em relação àqueles que o amavam”. Eis aí a grande "hamartía" de Narciso que (...) ultrapassou o métron (o que Liríope temia) e, encastelado em sua beleza, comete uma hýbris, uma violência contra Eros, contra o amor-objeto e contra o envolvimento erótico com o outro. (Brandão, 2013, p. 189)

Narciso parecia gozar do (e no) não laço (ao menos, de um laço ético). Reinara autossuficiente até sua queda (harmartía). A queda do herói trágico, descomedido em relação a si e ainda incapaz de amar (envolvimento erótico com o outro), deu-se em atroz imobilidade. Refletido nas águas, curva-se (aprisiona-se) para o pai. 
"Reflectere, de re-, 'novamente' e flectere, 'curvar-se', significa etimologicamente, 'voltar para trás” (Brandão, 2013, p. 192). Novamente curvado, retorno libidinal radical, Narciso reifica sua imagem como imagem criada pelo e para o pai. Faz da imagem consistência, confunde corpo e sombra. Crente, crê na imagem que veicula. Crê na ilusão de verdade-toda que seus olhos, em puro reflexo, veem.

Conforme Ovídio nos relata em suas Metamorfoses:

Ao procurar saciar uma sede, brota nele uma outra sede.

Enquanto bebe, arrebatado pela imagem de beleza que avista, ama uma ilusão de corpo. Crê ser corpo o que apenas é água.

Extasia-se ante si mesmo e fica imóvel, de rosto imóvel também, fica hirto como uma estátua de mármore de Paros.

Estendido no chão, contempla dois astros que são seus olhos; contempla seus cabelos, dignos de Baco e dignos de Apolo; contempla as faces, virginais ainda, o colo de marfim, a graça da boca e o rubor misturado a nívea brancura. Admira tudo o que o torna a ele digno de admiração. Sem o saber, a si se deseja; é aquele que ama, e é ele o amado. Ao cortejar, a si se corteja. Arde no fogo que acende. Quantos beijos inúteis deu na fonte que lhe mentia! Quantas vezes, para abraçar seu pescoço, que via no meio das águas, mergulhou os braços, sem neles se encontrar! Não sabe o que vê, mas o que vê consome-o! E a mesma ilusão que engana seus olhos, excita-os. Ingênuo! Por que buscas em vão agarrar uma fugitiva imagem? O que desejas não existe! O que amas, retirando-te, perde-lo-ás! Essa sombra que vês é o reflexo da tua imagem. Nada tem de seu! Contigo chega e contigo está. Partiria contigo, se tu partir pudesses! Nem a preocupação de Ceres, nem a necessidade de repouso o podem afastar dali. Estendido na erva, à sombra, contempla, com olhar insaciável, a enganosa imagem, e morre vítima de seus próprios olhos. (Ovídio, 8 d.C./2017, pp. 191-193, grifos nossos)

Narciso, para Ovídio, era, enfim, um crédulo em busca de algo que não poderia existir, em busca de uma imagem fugidia. Embevecidos por seus corpos-água, os Narcisos contemporâneos levam suas fontes (agora em redes virtuais e smarts) a uma extensão impossível ao herói grego. E, em espaço ampliado, imobilizam-se crentes daquilo que veiculam, postam, fotografam etc. Corpos assombrados, acorrentados a suas imagens, confundidos com suas águas. 
Há outra passagem do texto de Ovídio na qual Narciso faz um desabafo:

Será, florestas, que alguém amou com tão cruel sofrimento? Com certeza o sabeis, pois fostes para muito refúgio oportuno! Tendo vossas vidas atravessado tantos séculos, recordai-vos, nesse longo curso, de alguém que se haja consumido assim? Encanta-me e vejo-o, mas o que vejo e me encanta não consigo encontrar! Tal é o desvario que enreda a quem ama! E para maior penar, não é o vasto mar que nos separa, nem um longo caminho, nem montanhas, nem muralhas de portas fechadas. Somos impedidos por um pouco de água! Ele deseja meu abraço, pois sempre que eu levo meus beijos às límpidas águas, sempre ele se esforça por trazer até mim sua boca! Parece poder ser tocado. É o mínimo o que se interpõe entre quem se ama! Quem quer que tu sejas, vem até aqui! Por que troças de mim, jovem sem par? (...)

Esse sou eu! Apercebi-me disso e nem a minha imagem me engana! Abraso-me de amor por mim! Atiço e sofro o efeito das chamas! O que hei de fazer? Requestar ou ser requestado? Que hei de esperar? Em mim está o que cobiço. A riqueza me empobrece.

Oh! Pudesse eu separar-me do meu corpo! Estranho desejo de quem ama, querer eu que o objeto do meu amor esteja longe! A dor já me rouba as forças, e não me resta muito tempo de vida. Sucumbo na flor da idade. A morte não me é pesada, ela alivia-me as dores. Gostaria que aquele a quem amo tivesse mais longa vida. Agora, cordialmente unidos, morreremos ambos numa vida só. (Ovídio, 8 d.C./2017, pp. 193, 195, grifos nossos)

A água que faz/produz a imagem é também o que impede o gozo pleno ou, se quisermos, a relação sexual. Narciso desabafa: "somos impedidos por um pouco de água (...) é o mínimo que se interpõe”. E, ao perceber que aquele (do reflexo) era ele, clama pelo objeto (como se pudesse separar-se de si) e depois se funde cordialmente, em escolha pela morte.

Dos tempos do mito, a extensão que revela passagens repletas de soberba e de ausência de sofrimento parece ir dos momentos anteriores ao encontro de Narciso com seu reflexo até o princípio de seu arrebatamento ilusório. Há um Narciso autossuficiente, que passeia, zomba do amor, mostra-lhe a indiferença e goza da idolatria alheia e o Narciso arrebatado, a um só golpe idólatra e idolatrado. Narciso crente, feito das águas e aprisionado na imagem. No desabafo, entretanto, aparece a angústia diante do impossível do encontro e, sobremaneira, da constatação de 
que era ele aquele a quem amava. Um amor-por-si-sem-laço: um acordo cordial com a morte. Narciso parece mesmo ter tido sucesso em fazer Um com a morte.

\section{Espelho, espelho meu — os fundamentos do narcisismo}

Partamos do mito e, então, da constatação segundo a qual o narcisismo dá-se não sem o pai.

Se a psicanálise pode afirmar, desde Freud, que os narcisismos, primário e secundário, são fundamentais para a formação do eu, também sustentou a importância de certo afastamento, por parte dos sujeitos, da alienação que o narcisismo primário impõe. O eu-ideal, próprio ao narcisismo primário, eu investido libidinalmente, propicia trânsitos pulsionais fundantes, mas, não havendo uma ação psíquica que permita a saída do autoerotismo, não haverá laço. Entrementes, ainda restam aos sujeitos esforços para tentar recuperar aquele suposto estado inicial:

O desenvolvimento do ego consiste num afastamento do narcisismo primário e dá margem a uma vigorosa tentativa de recuperação desse estado. Esse afastamento é ocasionado pelo deslocamento da libido em direção a um ideal do ego imposto de fora, sendo a satisfação provocada pela realização desse ideal. (Freud, 1914/1996, p. 106)

A passagem, lógica, da alienação para a separação implica a ereção do ideal de eu: narcisismo secundário. E o que se passou a nomear narcisismo secundário pode mesmo ser lido como consubstancial à metáfora paterna.

O narcisismo secundário implica e ergue a ordem paterna. Não obstante, a leitura do mito nos permite pensar que o pai está posto desde o início. A imagem depende de sua intrusão. Desta feita, em conjunto com as descrições realizadas, uma questão pode ser lançada: como tratar a questão dos narcisismos (e sua importância na constituição dos sujeitos) sem cair em desenvolvimentismos?

Em trabalho anterior, procurei articular o texto do "Estádio do espelho", de Lacan, com a questão da identificação, pensando a formação do eu e a constituição do sujeito:

O passo lacaniano, dado a partir de sua teorização acerca da formação do eu, também apontou para a importância fundamental do outro naquilo que o psicanalista logo passaria a designar como constituição do sujeito. $\mathrm{O}$ outro, essa "exterioridade que é mais constituinte do que constituída" (Lacan, 1949/1998, p. 98). Através do texto "O estádio do espelho como formador da função do eu”, de 1949, Lacan procurou articular o estádio do espelho a uma identificação, "ou seja, a transformação produzida no sujeito quando ele assume uma imagem", o que também funda "a origem das identificações secundárias” (p. 97). (...) A assunção de uma imagem, conforme propôs Lacan, ocorre através de uma antecipação do sujeito, "o sujeito se anteci- 
pa numa miragem" (p. 98). O estádio do espelho, enquanto uma resposta à questão da prematuração do humano, foi, então, definido como "um drama cujo impulso interno precipita-se da insuficiência para a antecipação" (Lacan, 1949/1998, p. 99). (...) A identificação, processo matriz da formação e da constituição, passará a ser concebida como uma marca de linguagem. Uma marca singular advinda de Outro terreno que, enfim, antecede o próprio sujeito. Destaquemos, outrossim, que esta questão da antecipação foi colocada, a partir de seu retorno a Freud, em termos da primazia do simbólico e, logo depois, da primazia do significante. (Gianesi, 2011, p. 131)

Pois bem, o narcisismo implica uma identificação: isso ocorre quando o sujeito assume uma imagem. É possível mesmo afirmar que o espelho propicia uma identificação. Como identificação escópica, a imagem que se forma é corpo: “Se o ego é dito narcísico, é porque, em certo nível, há alguma coisa que suporta o corpo como imagem" (Lacan, 1975-1976/2007, p. 146).

O narcisismo está, desta feita, na base do que se designa por identificação em psicanálise. Mas, sabemos, a identificação, como conceito, ganhou bastante terreno após as elucubrações a respeito do conjunto espelho-corpo, ao qual acrescento — pai - , e que é possível ser formalizado como próprio ao elo Imaginário. Lacan passou, outrossim, longo tempo debruçado sobre as três identificações propostas por Freud, quais sejam, histérica, ao pai e ao traço, e provou a equivalência (Simbólica) entre elas. Sim, essa marca de linguagem, advinda de Outro terreno, própria ao campo do significante e do desejo, opera uma identificação por incorporação. A função paterna (metáfora paterna) faz-se patente.

A ordem paterna (como metáfora) está posta no quadro que Lacan propôs, na ocasião avançando na apresentação dos elementos mínimos de sua série simbólica, o seu "Esquema R":

Figura 1. Esquema R.

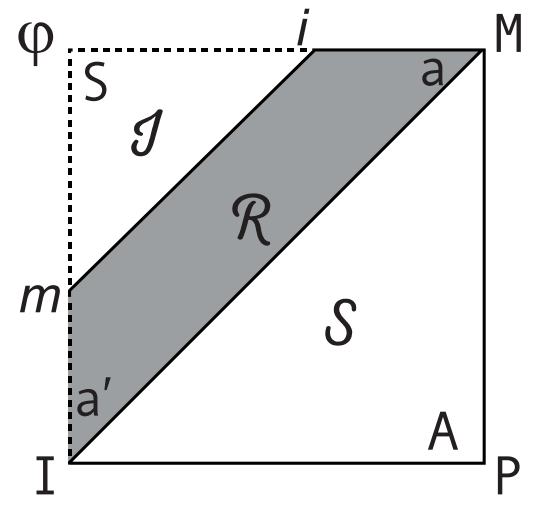

Fonte: Lacan, 1958/1998, p. 559. 


\section{RSI}

É interessante pontuar que Lacan colocou, em seu esquema, o Pai como correlato do Outro simbólico. É igualmente curioso pensar que tanto certa ordem paterna (pai imaginário e pai simbólico) quanto o corpo (corpo imaginário e corpo simbólico) estão presentes nessas construções. O corpo como Imagem e o corpo como Outro, tesouro de significantes que se incorpora, fazendo corpse, estão colocados na ordem da constituição. Sem qualquer um vir "primeiro", o esquema é antes lógico que cronológico. Entretanto, ainda é preciso pensar a dimensão Real ali implicada. Mais tarde, em seu persistente esforço de transmissão, Lacan articulou o Real à vida e, em relação ao corpo (corpo real), deixou claro que a vida atrela-se à pulsão e ao fato de que um corpo tenha furos (Lacan, 1975-1976/2007, p. 144). O corpo, como Real, não seria, justamente, o que é próprio à dimensão topológica do furo? Do furo que pulsa. Muito embora enigmático e estranho, o Real do corpo mostra-se e retorna.

E a ordem paterna? Lacan, em seu seminário sobre o Sinthoma, momento em que afirma ser o nó borromeano o Real, também designa o nó como função do pai: “Até onde vai, se posso dizer assim, a pai-versão? - escrita como vocês sabem, desde o tempo em que a escrevo. A pai-versão é a sanção do fato de que Freud faz tudo se ater na função do pai. E o nó bo é isso" (Lacan, 1975-1976/2007, p. 146).

Encontramos aqui uma referência sobre articulações entre corpo-pai-real. Isso como versão do pai, uma pai-versão. Um pai real?

A questão aberta sobre o conceito de identificação, que colocou os elos Imaginário e Simbólico em articulação com as dimensões paterna e do corpo, agora pode apontar para seus avanços no que concerne ao Real. Lacan pensou, por fim, em uma identificação da ordem de uma operação matemática como junção de pontos idênticos, distinguindo-a das identificações da série simbólica, e a denominou, derradeiramente, identificação ao sinthoma (Real). ${ }^{1}$

1 “Como, colocaria eu a questão, (...) como identificar a identificação histérica, a identificação amorosa, dita ao pai, e a identificação que eu chamaria neutra, aquela que não é nem uma nem outra, que é a identificação a um traço particular, a um traço que eu chamei (...) a um traço qualquer? Como repartir essas três inversões de toros, homogêneas, portanto, na sua prática, e, além do mais, que mantém a simetria, se posso dizer, entre um toro e um outro, como reparti-las, como designar de uma maneira homóloga a identificação paterna, a identificação histérica, a identificação a um traço que seja somente o mesmo?" (Lacan, 1976-1977, aula de 16 de novembro de 1976, inédito, grifos nossos).

Lacan pareceu bem claro quanto à equivalência entre as três identificações propostas inicialmente por Freud: podem ser lidas como o mesmo.

Em seu Seminário 24, Lacan, por fim, pensa em outra ordem de identificação. Podemos traduzir sua indagação da seguinte forma: como pensar uma identificação que permita a instauração de um nó heterogêneo? 
Há possibilidades de articularmos, destarte, Imaginário - corpo imaginário identificação imaginária - pai imaginário; Simbólico - corpo simbólico - identificação simbólica - NP; e Real - corpo real - identificação real - pai real. RSI.

Guardemos isso por enquanto.

\section{"Narciso acha feio o que não é espelho" (Caetano Veloso)}

Se o narcisismo é fundamental para a formação do eu, bem como para a consubstancial constituição do sujeito, o que pensar sobre a fixação (ficção e fixão) identitária que ele provoca?

Paradoxo posto de partida: aquilo que é crucial para a identificação fundante de cada um, ao ser cultivado em berço esplêndido, provoca inevitáveis alianças cínicas com o que é próprio (o próprio eu ou os “eus” próximos).

Pois bem, o narcisismo, que constitui o idêntico a partir da imagem paterna, quando fixo, quando inflado, quando inflacionado pelas políticas econômicas, aquelas das pequenas diferenças, torna grandiosos os iguais, torna totalitário o comando, torna o não idêntico do furo, da contingência, do não-todo, descabido, descartável, não possível, desprezível.

É interessante pensarmos os fenômenos cada vez mais presentes das aparições, bastante covardes (de uma típica valentia covarde), daqueles que vociferam sem corpo, dos haters virtuais ou daqueles tanto ou ainda mais covardes, dos haters de corpo presente, isso em relação ao fenômeno crescente do narcisismo espetacular/ especular (com o perdão da redundância). Debruçados sobre as articulações entre o narcisismo e os ódios, lembremos que Lacan, em "A agressividade em psicanálise”, já havia sustentado sua Tese IV: “A agressividade é a tendência correlativa a um modo de identificação a que chamamos narcísico, e que determina a estrutura formal do eu do homem e do registro de entidades característico de seu mundo" (Lacan, 1948/1998, p. 112).

O narcisismo, pela via da identidade sectária, isola e une, afasta e congrega, despedaça e faz Um. O ódio ao supostamente estrangeiro e o "amor" ao brilhante semelhante cinde radicalmente: o que é do recôndito privado, o mais fechado quintal de cada igual, e o que é outro - desprezíveis baratas esses outros! Há, entretanto, algo altamente capcioso nesse espelho capital das novas eras: ele se propõe engolir a própria crítica que faria da separação um ato possível. Desde a separação em relação à alienação exigida por pequenos grupos e/ou instituições

Dizemos que, como função, o sinthoma nos mostra aquilo que do inconsciente pode traduzir-se por uma letra, com o esclarecimento de que nessa letra a identidade de si a si permanece isolada de qualquer qualidade. A identificação, nesse caso, como identidade de si a si, envolve o que em matemática se designa por junção de pontos equivalentes. Desta feita, parece plausível a proposta que aqui se desenha segundo a qual essa identificação, heterogênea em relação às demais, seja considerada Real (um encontro de pontos idênticos, sem predicação, fora do campo do sentido). 
até movimentos sociais que lutam por fazer proliferar a já desgastada consciência de classe. Assistimos, muitas vezes inertes, à patente marca da deglutição e ao espetáculo feérico da oferta dos iguais, estes que deixam montado o ideal especular (com a presente leitura do mito, assevera-se que espelho e ideal podem mesmo convergir). E, claro, o produto dessa tentativa constante de fazer valer o absoluto é o resto-dejeto ou o espelho-estilhaço, a “desimagem” do desumano.

\section{Nós-todos-narcisos}

Uma comunidade de analistas que ainda preze a crítica assídua do que se diz em nome da psicanálise poderia reabrir a boca para dar voz a alguns problemas que o narcisismo em culto e a sustentação paterna (a todo custo) podem causar, sobremodo no que toca às discussões sobre os fins de análise.

Colette Soler propôs em seu texto "Nova economia do narcisismo" (2017) três narcisismos, a saber: narcisismo da imagem, narcisismo do desejo e narcisismo de gozo. Acompanhemos seus argumentos. Primeiro, o narcisismo da imagem (já com a entrada para pensarmos o narcisismo do desejo):

Certamente, neste estádio, a imagem se torna o primeiro objeto; então, podemos ver aí um estádio da libido, porém esse amor da imagem é determinado por outra coisa, a saber, a função identitária: ela é constituinte de um primeiro estrato da identidade. Daí podemos dizer que é a questão fundamental, implícita, à qual responde o estádio do espelho: saber como a criança, que é um pequeno organismo, um pequeno animal, se torna um humano socializado e socializável (...). Aqui a identificação é reconhecida como o instrumento primeiro da socialização. O que será que funda a importância, e até mesmo a necessidade dessa primeira identificação no pequeno homem? (...) Lacan responde: a identificação é necessitada pelo efeito de falta-a-ser do sujeito que a linguagem produz. (Soler, 2017, pp. 28-29)

O efeito de falta-a-ser do sujeito da linguagem provoca a identificação imaginária (atrelada ao narcisismo da imagem). O pai como função e significante é o que, a um só tempo, fornece a imagem, propicia-a e a limita (em termos de gozo). A imagem se forma pela intrusão significante. O que antes fora aqui pontuado na leitura para o mito. O pai de Narciso, sendo uma referência das águas, possibilitou a formação da imagem.

O narcisismo do desejo: "O narcisismo do desejo consiste em se identificar aquilo que empurra vocês na vida, geralmente sem saber o que empurra, é isso o desejo. Sua forma mais notável é 'não ceder sobre seu desejo' (...). Ora, Antígona, que não cede, é o narcisismo do sujeito" (Soler, 2017, p. 38).

Soler havia pontuado um enlace entre o narcisismo da imagem e aquele do desejo, propondo a ideia de um "espelho falante (...). Espelho, diga-me que sou a 
mais bela? Portanto, é um espelho suposto saber" (Soler, 2017, p. 34). O narcisismo, do "espelho, espelho meu” é, de partida, um enlaçamento entre Imaginário e Simbólico. A ordem significante, posta no mito pela intrusão paterna, está dada desde o início, ou melhor, cava o lugar que referimos como "inicial”. Retomando o texto de Soler: "O espelho é o Outro que se torna presente pelos outros, e paradoxalmente coloca o pequeno Narciso do estádio do espelho à mercê do desconhecido, pois subordina a relação à imagem primária, à relação ao Outro barrado" (Soler, 2017, p. 34, grifo nosso).

Pareceu-me surpreendente o encontro, no próprio mito, dessa afirmação: ali, na construção greco-romana, o espelho (como pai) é mesmo o Outro (também assim localizado no esquema $\mathrm{R}$ ).

E, finalmente, o narcisismo do gozo:

Quando Lacan (...) evocou a "identificação ao sintoma”, em que se trata de gozo (...) esse passo introduz uma radicalização (...). Até aqui podíamos desconhecer a ameaça que o narcisismo faz pesar sobre o laço social, pois o desejo, sendo desejo do outro, o narcisismo do desejo não era tão associal assim. Com o narcisismo do gozo, que consiste em não ceder sobre a afirmação de sua modalidade de gozo e a se identificar, ou seja, não ceder sobre a preferência que cada um tem à sua própria, pois bem, as coisas mudam, pois o gozo, contrariamente ao desejo, não é determinado pelo Outro, o lugar da linguagem, mas pelos acidentes da conjunção entre lalíngua e o corpo (...). Então, vem a questão, o que pensar do poder analítico da fala da verdade, sempre meia-dita sobre as fixões de gozo? O que pensar dos sujeitos produzidos pela análise que chegou ao fim? Não poderiam esses sujeitos identificados ao seu gozo ser uns sobrenarcisos, dessa vez tão autossuficientes quanto Narciso antes de encontrar sua imagem? E o que pensar do laço social, pois o gozo não enlaça? (Soler, 2017, pp. 38-39)

As Suficiências que se espalham em um não-laço-disparatado poderiam mesmo relacionar-se com o narcisismo, com o que, enfim, Soler propôs como narcisismo do gozo. Há, sem dúvida, ênfase dada à ipseidade nas declarações sobre o "gozar do inconsciente" feitas por Lacan quando às voltas com a identificação com o sintoma. Acrescido a isso, caso nos seja possível ler pontuais articulações desse a respeito do savoir y faire com o sintoma (cada qual com o seu) e com a imagem (cada qual com a sua), talvez possamos avançar na formalização desses sobrenarcisos como produtos de fins (topologicamente escritos). Vejamos:

Conhecer quer dizer saber lidar com (savoir faire avec) esse sintoma, saber desembaraçá-lo, saber manipulá-lo, saber - isso tem alguma coisa que 
corresponde ao que o homem faz com sua imagem — é imaginar a maneira pela qual a gente se vira com esse sintoma. Trata-se aqui, certamente, do narcisismo secundário; o narcisismo radical, o narcisismo que chamamos primário estando, nessa ocasião, excluído. Saber se virar (savoir y faire) com o seu sintoma, está aí o fim da análise. (Lacan, 1976-1977, aula de 16 de novembro de 1976, inédito, grifos nossos)

Lacan propôs essa articulação entre o saber fazer com a imagem e o fim de uma análise. Quiçá possamos localizar aqui uma das origens de nosso embaraço. Certa confusão (topológica) entre um enlace que privilegia o imaginário e outro que sustentaria o real e a ética que lhe concerne. Saber fazer com a imagem (sem recusar aqui a importância do corpo, do colocar o corpo, mas já destacando que o corpo que tratamos de sustentar é um corpo furado) talvez seja um modo de não irmos além do pai.

Podemos encontrar no texto "Desenodamento", de Bousseyroux (2012), algumas colocações com as quais conversarmos:

De que a identificação de fim é a assinatura? Daquilo que, no sintoma, no seu real, não é metafórico, quer dizer, não é substituível. Exceto que aí está o problema todo. Porque a metáfora é inerente ao nó borromeano, incluindo aquele de quatro do sintoma (...). Mas, então, como pensar borromeanamente o fim, se o bicho do sentido encontra-se na fruta do nó pelo sintoma que Lacan nomeia também de sintoma? (...) é por isso que Lacan reluta a identificar o inconsciente real a uma das cordas do nó borromeano: porque dando a uma delas o nome de real, dá-se sentido ao real. De tal forma Lacan encontra em sua aproximação borromeana do real uma contradição intrínseca ao nó canônico R.S.I.: ao mesmo tempo, sua colocação mostra que o real é expulso do sentido e, ao mesmo tempo, o fato de nomear de Real uma das três cordas lhe deu sentido tornando-o substituível às outras duas cordas, assim o real torna-se metafórico. O real do enodamento borromeano ao terceiro é uma metáfora da relação sexual que não há a dois e esta metáfora do impossível coloca obstáculo à manifestação do real como expulso do sentido. Aliás, é por isso que é necessário o quarto: para sair do vespeiro da trindade. Mas, mesmo com o nó de quatro pelo sintoma - que cria um nó heterogêneo onde, os quatro sendo acoplados dois a dois, a substituibilidade só é possível no interior de cada dupla, o problema da metáfora que vem do nó continua sem ser resolvido (...). Vemos que esta questão ultrapassa a estrutura real do Borromeo, ela requer um salto ético (...). É possível que a interpretação opere ao nível mesmo do nó de tal modo que sua metáfora, que oferece novamente sentido ao real, se reduza? (...) Lacan descobre que essa redução é borromeanamente possível. É suficiente para isto que se ate a corda do sintoma, que, na cadeia de quatro, 
é necessariamente acoplada àquela do simbólico, a uma das duas cordas do outro par dessa cadeia, o que só deixa a escolha entre atar o sintoma ao imaginário ou o atar ao real. (Bousseyroux, 2012, pp. 36-37)

Bousseyroux (2012) acompanha os problemas que Lacan enfrentou na transmissão pelo nó. A questão parecia ser: como transmitir o que, por ser Real, não é metafórico (portanto, não é substituível)? A boca voraz do sentido escreve-se no nó, e aquilo que o primeiro designou por "vespeiro da trindade" mantém a colocação de sentido para o Real. O que é um contrassenso, claro. Igualmente, o nó a quatro (um nó heterogêneo em relação ao nó de três, confeccionado a partir de um quarto elemento que enoda e assim realiza o borromeano) ainda mantém o impasse sobre o Real. O Real, assim, dito, ganha sentido. O que escancara uma nova pergunta: como operar no nível do nó de modo a reduzir o campo metafórico?

Bousseyroux (2012) enfatiza, outrossim, a necessidade de um passo ético! Sublinho essa expressão, pois há necessidade de um passo ético também em relação à problemática que certo narcisismo categórico nos impõe.

Pois bem, na cadeia borromeana a quatro, o elo do sintoma está necessariamente acoplado àquele do simbólico (já que o sintoma é uma nomeação simbólica). Esse modo nodal pode, esticado, acoplar-se dois a dois ${ }^{2}$ (o que permite a substituição no interior de cada dupla). Por causa dos princípios dessa ordenação, uma operação de redução do nó é topologicamente possível. Por homotopia, ${ }^{3}$ é possível atar o nó do sintoma ao real ou ao imaginário:

\footnotetext{
2 Quando há enodamento a quatro pelo sintoma (que é uma nomeação simbólica), o elo do sintoma ficará atrelado, necessariamente, ao elo do simbólico, de modo a não conseguirmos fazer um nó simétrico se puxarmos sintoma de um lado, simbólico de outro (cada elo atrelado a apenas um elo nessa configuração). Teremos nós simétricos (aptos à operação de equivalência homotópica) se "puxarmos pela orelha", estabelecendo o dois a dois, real de um lado, simbólico de outro, ou imaginário de um lado, simbólico de outro, de modo a ficarem — no meio — imaginário/sintoma e real/sintoma, respectivamente.

3 Homotopia é uma operação de deformação topológica que pode ocorrer em determinado intervalo de tempo (se tomarmos o tempo como parâmetro). Uma equivalência homotópica se dá a partir da noção de igualdade (identidade) extraída da própria deformação. Dois laços são considerados homotópicos se um puder ser deformado continuamente no outro. Laços triviais (os elos do nó - retas infinitas que se encontram em si para formar o "círculo" de cada dimensão do nó) que estejam trançados topologicamente de modo a constituírem um nó borromeano (um dos tipos de nó brunniano) podem, por corte, fazer continuidade homotópica (entre dois desses laços). Isso não acontecerá entre quaisquer elos, mas, seguindo a operação permitida, provocará autocruzamentos, que, por sua vez, farão do nó um nó que estará ao mesmo tempo enodado e desenodado (trivializado) (Bousseyroux, 2012; Uribe, 2013; Araldi, sem data).
} 
Deixo de lado a colocação em continuidade do sintoma com o imaginário, que interessa mais à psicose, e me detenho aqui em sua ligação com o real, na medida em que a redução do sintoma ao real fora do sentido do gozo é o que visa o equívoco da interpretação. Lembro-me que Lacan define também o equívoco em 1975, vendo ali a abordagem eleita do inconsciente para daí reduzir o sintoma (...): ela (a interpretação) reduz o sintoma "por contradizer o sentido”. (Bousseyroux, 2012, p. 37)

Penso que poderíamos estabelecer diferenças importantes: apostemos que os atares entre o imaginário e o sintoma e aquele entre sintoma e real são distintos. Talvez possamos pensar que o gozo narcísico de fim, daqueles que terminaram suas análises sabendo "lidar" com sua imagem e, portanto, com o narcisismo secundário, que gozam, então, de seus sintomas, sintomas cheios de qualidades, em uma espécie de sem fim de predicação, estão estruturalmente fazendo valer a operação homotópica entre sintoma e imaginário. Não acredito, enfim, que devamos estabelecer esse modo nodal como restrito à psicose.

Em seu Seminário 24, Lacan (1976-1977, inédito) havia apresentado o curso de uma análise em termos nodais. Mostrou-nos como, muitas vezes, o analisante revira o toro Simbólico do nó (sendo um nó formado pelo enlace de toros), de modo a envelopar Real e Imaginário, formando, então, um trique, um cilindro-corpo, armadura neurótica sustentada pelo pai. Esse trique, fazedor de sentido, corre por bastante tempo em uma análise, o que faz o analista suportar as construções analisantes em torno da novela edípica, do terreno das identificações, do sentido da neurose de cada um etc. Seria também relevante pensarmos alguns modos de apresentação próprios ao envelopamento pelo Imaginário (dos toros do Simbólico e do Real). A castração, relativa ao gozo fálico, estaria ali "escondida". O sobrenarciso, ultra-autossuficiente, passeia aqui com suas vestes-armaduras. Com isso, explicar-se-ia o inflar imaginário, notórias dificuldades associativas etc. Um envelopamento narcísico seria correlato de um envelopamento especular. A ordem simbólica parece desaparecer. E o Real fica evitado. Não deixa de ser importante pontuarmos que essa aparência de Suficiência é um aprisionamento à imagem.

Lacan propôs, em relação ao trique, que haveria a necessidade, no fim de uma análise, de uma contrapsicanálise para que se possa restaurar o nó em sua forma original. RSI. No caso de um envelopamento pelo Imaginário, dos heróis narcisos que eventualmente nos chegam, seria preciso uma operação a mais? Quais sejam: um, o restaurar simbólico e, depois, a chamada contrapsicanálise?!

De qualquer modo, restaurado o nó, caímos no dilema da trindade ou, caso possamos arcar com o nó a quatro, nas diferenças cabíveis entre a identificação narcísica de fim e a sustentação ética do não-todo. 
Desta feita, tendo a identificação ocorrido pela via do narcisismo (identificação com o pai-espelho-rio), a operação nodal terá se dado entre o sintoma e o imaginário.

Em um reduto de sujeitos privatizados por seus gozos próprios, ou (o que dá no mesmo) de Narcisos inflados e cheios de qualidades, o espelho-pai faz verdade toda, e a dimensão pulsional da voz petrifica-se. O olhar exige idolatria, e a voz permite apenas ecolalia. Nós-todos-narcisos.

É interessante apontar que, nesses casos, Cefiso-pai erige-se bastante consistente. As dimensões paternas do narcisismo e do sintoma aqui coincidem. Destarte, podemos colocar o Narciso Ingênuo da "feliz" autossuficiência e o Narciso da fonte (sofredor) como equivalentes, como igualmente aprisionados pelo destino paterno. Esse Outro que lhe faz espelho-falante (gozoso). Ou seja, pensando sobre momentos analíticos ou sobre possíveis fins por uma via narcísica, isso a partir da topologia (envelopamentos de nós ou enodamentos), podemos sustentar que os três narcisismos (da imagem, do desejo e do gozo) são equivalentes e sustentam-se por uma via paterna. Cefiso-pai-Narciso enodante.

Entretanto, ainda interrogando os nós, ser-nos-ia possível sustentar o não-todo e, por isso mesmo, a ética da identificação com o sinthoma (não mais afinada apenas com o gozo que não enlaça ou ao lidar com a própria imagem, a não ser que seja para cavar nela seus furos), em um além da Lei (mas não sem esta)? O gozo que não enlaça estaria restrito a uma letra-nome-vazio, e o vazio (como causa) poderia, esse sim, enlaçar por uma aposta ética pelo não-todo? Sustentação, no laço, de S de A barrado, furo?

Lembremos que, quando Lacan propõe "o saber se virar com isso" (savoir y faire), ele também se refere às variedades (ali equivocava variedade, verdade e variável (x)): "Repito: o que o analisante diz, esperando verificar-se, não é a verdade, é a vari(e)dade do sinthoma” (Lacan, 1976-1977, aula de 18 de abril de 1977, inédito).

Com a variável (x), enigmática, com a variedade do sinthoma (que está sustentado pelo não-todo da verdade), dizemos que cada sujeito singular goza de seu inconsciente, de alíngua. Sim, como afirmado, esse gozo não enlaça. Esse gozo não basta para o laço, não satisfaz o laço. Entretanto, sendo um gozo concernente ao vazio da letra-cifra-signo e propício a invenções, não haveria sobremodo uma responsabilidade do analista em sustentar (não seu gozo), mas o ponto vazio que o sustenta? E isso, justamente, no laço?

(Aqui recolocaríamos a discussão - como um parêntese - sobre a ideia de identificação com o sinthoma, com (th) como operação matemática, como redução à variável $\mathrm{x}$, que faz uma identidade de si a si sem predicações ou qualidades. Uma identidade, portanto, não identitária. Essa identificação seria, então, relativa a um ponto de equivalência, a uma função, e não a qualquer significado.)

Para concluir, novamente Bousseyroux (2012): o autor afirma, enfim, que o Real (inconsciente real) se escreve borromeanamente enodado pela letra do sintoma. 
Indaguemo-nos: o que seria a escrita e a leitura dessa letra-signo-cifra do sinthoma (com th)? Uma escrita contingente de uma cifra (signo) enigmática que suspende o sentido da neurose. De modo diverso ao nó sustentado (e estabilizado) pelo narcisismo (na junção entre imaginário e sintoma), o enodamento pela letra-signo-cifra do sinthoma seria um nó desinflado (a própria prova/sustentação do não-todo). Recorramos à homotopia:

Há uma propriedade da topologia que estabelece a noção de relação de equivalência por homotopia afirmando que, em uma cadeia, dois círculos não podem em nenhum caso atravessar um ao outro, mas que um círculo pode perfeitamente se atravessar a ele mesmo se ele passa por cima ou por baixo de seu próprio caminho, este acima se tornando abaixo e este abaixo se tornando acima. Esta propriedade é aplicável ao laço do sintoma real, permitindo-lhe autoatravessar em três de seus cruzamentos e também de desfazer sem a tesoura o nó de três (...). (Bousseyroux, 2012, p. 37)

Bousseyroux (2012) nos mostra que esse nó por homotopia é reversível. É um nó que a um só tempo enoda e desenoda. O verbo (como Simbólico) e o corpo (como Imaginário) e o Real estão enodados e desenodados, provando um Real não enodado do gozo (fora do sentido). Um real que só se prova por ser corte. Levando-se em conta mais seu desaparecimento que sua aparição. ${ }^{4}$

Figura 2. Nó borromeano generalizado.
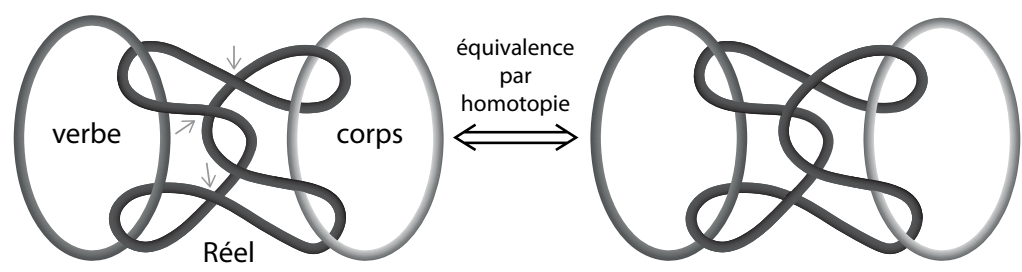

les trois sont dénoués sans coup de ciseaux

Fonte: Bousseyroux, 2012, p. 38.

\begin{abstract}
4 Bousseyroux (2012) propõe uma estabilização desse nó homotópico - real e sinthoma. Entrementes, o aspecto contingente dessa escrita (de um nó que ao mesmo tempo enoda e desenoda) parece "provar" melhor o real por seu desaparecimento (fracasso, tropeço, claudicação). Afinal, pode ser bastante perigosa a consistência de fim, que resvala ou mesmo congela predicações infinitas (o que estaria explícito em uma operação posta entre imaginário e sintoma). Mais interessante poderia ser a manutenção da responsabilidade advinda de uma experiência de vacuidade.
\end{abstract}


O não-todo como furo, como experiência contingente, não poderia, sobremaneira, enlaçar eticamente?

E, mais ainda, como sustentar a contingência, se ela é provisória? Não haveria alguma necessidade posta na sustentação do furo que a contingência cava?

Encontrei, em uma exposição de Kazuo Wakabayashi e no livro de Tomimatsu sobre o artista, uma citação de Deleuze que dá dignidade ao necessário em uma justa sustentação da contingência: "o signo é o que nos faz pensar. O signo é objeto de um encontro; mas é precisamente a contingência do encontro que garante a necessidade daquilo que ele faz pensar" (Deleuze, 2010 citado em Tomimatsu, 2017, p. 26). 


\section{Referências bibliográficas}

Araldi, A. A. R. (sem data). Revista Ensino \& Informação. Obtido em 21 de maio de 2018. Recuperado de http://www.ensinoeinformacao.com/topologia-algebrica-homotopia

Bousseyroux, M. (2012). Desenodamento. Wunsch: Boletim Internacional da Escola de Psicanálise dos Fóruns do Campo Lacaniano, Paris: EPFCL, (13), 35-39.

Brandão, J. S. (2013). Mitologia grega (22a ed., Vol. II). Petrópolis: Vozes.

Freud, S. (1914/1996). Sobre o narcisismo: uma introdução (Jayme Salomão, Trad.). In J. Strachey (Ed.), Edição standard brasileira das obras psicológicas completas de Sigmund Freud (Vol. XIV, pp. 81-110). Rio de Janeiro: Imago.

Gianesi, A. P. L. (2011). Causalidade e desencadeamento na clínica psicanalítica. São Paulo: Annablume.

Lacan, J. (1948/1998). A agressividade em psicanálise. In J. Lacan. Escritos (Vera Ribeiro, Trad.) (pp. 104-126). Rio de Janeiro: Jorge Zahar.

Lacan, J. (1958/1998). De uma questão preliminar a todo tratamento possível da psicose. In J. Lacan. Escritos (Vera Ribeiro, Trad.) (pp. 537-590). Rio de Janeiro: Jorge Zahar.

Lacan, J. (1975-1976/2007). O seminário, livro 23: s sinthoma (Sergio Laia, Trad.). Rio de Janeiro: Jorge Zahar.

Lacan, J. (1976-1977). Le séminaire, livre XXIV: l'insu que sait de l'une-bévue s'aile à mourre. Inédito.

Ovídio (8 d.C./2017). Metamorfoses (Domingos Lucas Dias, Trad.). São Paulo: Ed. 34. Soler, C. (2017). Nova economia do narcisismo (Maria Vitori Bittencourt, Trad.). Stylus: Revista de Psicanálise. Rio de Janeiro: EPFCL-Brasil, (34), 27-44.

Tomimatsu, M. F. (2017). Kazuo Wakabayashi: um artista imigrante. São Paulo: Porto de Ideais.

Uribe, O. E. O. (2013). Grupos de tranças brunnianas e grupos de homotopia da esfera $S^{2}$. (Tese de doutorado, Instituto de Matemática e Estatística). Universidade de São Paulo, São Paulo, SP.

Recebido: 08/04/2018

Aprovado: 12/06/2018 